\title{
INTERMITTENT FASTING CAUSES METABOLIC STRESS AND LEUCOPENIA IN YOUNG MICE
}

\author{
O. M. SOROCHYNSKA ${ }^{1}$, M. M. BAYLIAK ${ }^{1}, Y$. V. VASYLYK ${ }^{1}$, \\ O. V. KUZNIAK ${ }^{1}$, I. Z. DROHOMYRETSKA ${ }^{1}$, A. Ya. KLONOVSKYI ${ }^{1}$, \\ J. M. STOREY' $Y^{2}$ K. B. STOREY $Y^{2}$, V. I. LUSHCHAK ${ }^{1 \bowtie}$ \\ ${ }^{1}$ Vasyl Stefanyk Precarpathian National University, Ivano-Frankivsk, Ukraine; \\ ${ }^{2}$ Institute of Biochemistry, Carleton University, Ottawa, Canada; \\ e-mail: lushchak@pu.if.ua
}

Received: 29 October 2018; Accepted: 13 December 2018

\begin{abstract}
Overweight and obesity became the worldwide epidemic resulting from overeating especially when a so-called Western diet rich in carbohydrates and fats is used. It is widely accepted that limitation of food consumption could help to withstand such state of adult organism, but information about younger groups is contradictory. The present study was undertaken to characterize the effects of intermittent fasting, using an every other day (EOD) fasting/feeding protocol, on hematological parameters and biochemical blood plasma indices in young mice from one to two months old. It was shown that intermittently fasted mice were characterized by a reduced body weight, reduced total number of blood leucocytes, lower glucose and lactate levels and higher activity of alanine aminotransferase and aspartate aminotransferase in blood plasma as compared with the age-matched control mice. To gain the same mass EOD animals needed to eat more food than ad libitum fed animals. These differences may probably be explained by a need to expend certain resources to combat stress induced by intermittent fasting. Our data showed that EOD feeding at a young age may negatively influence young mammals.
\end{abstract}

Ke y w o rd s: aminotransferases; glucose, blood plasma, leucocyte formula, intermittent fasting.

$\mathrm{R}$ egulation of food intake relative to an ad libitum diet is known as dietary restriction (DR). DR has been found to extend mean and maximum lifespan and health span of a multiple species ranging from bacteria to humans and also influences diverse age-related pathologies [1,2]. Such restriction was found to decrease body mass and normalize blood glucose, insulin, and leptin levels in obese animals and humans. In addition to effects on peripheral tissues, DR improves the operation of the central nervous system and weakens symptoms of age-related neurodegenerative disorders in rodent models [1-7]. There are two different approaches to model DR with rodents. In one approach, animals receive food daily, but the amount of food is specifically limited according to the experimental design, which is usually $30-40 \%$ less than the ad libitum (AL) consumption. The second approach, called in- termittent fasting (IF), provides animals with food for certain periods, whereas at other times they do not have access to food; e.g. animals could be deprived of food for a full day, or for every other day, or for one day in three, and are fed AL on the intervening days $[8,9]$. One more version of DR may be proposed: organisms follow an IF schedule but on feeding days they do not eat ad libitum, but receive a lower amount of food (e.g. 30-50\% of ad libitum). Interestingly, although the first two approaches for DR mentioned above look different, most parameters that have been monitored in animals are similar between the two: e.g. decreases in body mass, body temperature, heart rate, blood pressure, and glucose and insulin levels $[9,10]$. Diverse molecular mechanisms are believed to be responsible for the beneficial DR effects, the common ones being improved insulin signaling, altered operation of mitochondria

(C) 2019 Sorochynska O. M. et al. This is an open-access article distributed under the terms of the Creative Commons Attribution License, which permits unrestricted use, distribution, and reproduction in any medium, provided the original author and source are credited. 
and their biogenesis, a decrease in steady-state levels of reactive oxygen species, and induction of a cytoprotective cellular stress response.

Mice are very popular laboratory mammalian models for numerous purposes. Indeed, of relevance to the current work, various studies of caloric restriction have been carried out with a mouse model and showed positive results with these animals [11, 12]. However, from analyzing the literature on multiple modes of food restriction, we propose that IF is a more relevant mouse model of DR than is a permanent limitation on food because in the IF model animals can be kept in groups of 3-5 animals per cage which is more typical for these social animals. In addition, competition for food is avoided because mice have permanent access to it at feeding time. Finally, IF is probably closer to the natural experience for mice where if animals find food they usually eat as much as possible and this can compensate for periods of unknown duration when food is cannot be found. Surprisingly, despite the broad use of CR and IF approaches in dietary studies, a systematic evaluation of the effects of IF on blood parameters virtually is missing, especially for young animals. Similar data for humans is also scarce. Therefore, in the present study, we evaluated some "classic" parameters of the blood system under IF in young mice in order to provide fundamental information for the future broad utilization of the model. Importantly, most of the parameters studied here can be easily measured vitally, i.e. the use of one or more of these parameters could be followed over the long term (with serial sampling of individuals) as a marker for positive or negative effects of dietary modulation under different conditions of interest. The present study reports that IF mice had lower body mass, plasma glucose levels and white blood count as compared with their AL counterparts.

\section{Materials and Methods}

Reagents. Phenylmethylsulfonyl fluoride (PMSF), $\mathrm{KH}_{2} \mathrm{PO}_{4}, \mathrm{NaCl}$, ethylenediamine-tetraacetic acid (EDTA), sodium L-lactate, sodium pyruvate, and hydrazine were purchased from Sigma-Aldrich Corporation (USA); NADH, NAD ${ }^{+}$, glycine, lactate dehydrogenase were from Carl Roth Corporation (Germany); diagnostic kits for determination of glucose, triglycerides, and total cholesterol levels, alanine aminotransferase (ALT), aspartate aminotransferase (AST) and alkaline phosphatase (ALP) were from Phyllis-Diagnosis (Dnipro, Ukraine). All other reagents were obtained from local suppliers (Ukraine) and were of analytical grade.

Animals and experimental conditions. The mice used in this study were mixed a C57BL $\times_{\text {Sv1 }} 29$ strain kindly provided by Dr. I. Shmarakov from Yuriy Fedkovych Chernivtsi National University (Chernivtsi, Ukraine). All animals were bred in our department in a closed colony, housed under standard laboratory conditions (12-h light/dark cycle, $22 \pm 2{ }^{\circ} \mathrm{C}$ temperature, and 50-60\% humidity). One-month-old mice of both sexes were randomly assigned to the ad libitum (AL) control group or to the every other day fasting (EOD) regimen. Mice in the control group were allowed access to food at any time. Experimental mice were subjected to the EOD regime where animals had free access to food for $24 \mathrm{~h}$ alternating with food deprivation for next $24 \mathrm{~h}$. Food was provided to the IF groups at 9 a.m. and withdrawn at 9 a.m. on the next morning. All mice received a regular chow, "Rezon-1" Co, Kyiv, Ukraine (LabDiet K 120-1: 21.8\% protein, 4.8\% fat, $3.9 \%$ fiber) and had free access to water all times. Mice were separated by sex and housed in groups of 4-5 mice per cage at the initiation of the study and kept on their respective diet regimes for one month. All mouse protocols were approved by the Animal Experimental Committee of Vasyl Stefanyk Precarpathian National University and were conducted in accordance with the European Communities Council Directives (86/609/ECC). Body mass and food consumption were evaluated once per six days. All animals survived until the end of the experiment. Age-matched littermate controls were used for each experiment. Statistical methods were not used to predetermine sample size and investigators were not blinded to allocation during experiments. Huddling or coprophagic behaviors were not prevented. At the end of the experiment, mice were euthanized using carbon dioxide gas anesthesia and blood was taken from the retro-orbital sinus. All animals (both AL and IF) were sampled about 11-12 a.m. and before this food was withdrawn at 9 a.m.

The experimental groups used two designs. In the first experimental regime IF animals were sampled the day after a feeding day and food was withheld for $2 \mathrm{~h}$ (exactly like control group) before euthanasia. In the second IF design mice were euthanized the day after a starvation day, again beginning at $11 \mathrm{am}$ (a total fasting period of $26 \mathrm{~h}$ ). Levels of blood glucose, lactate, cholesterol and activities of alanine aminotransferase (ALT) and aspartate aminotrans- 
ferase (AST) were measured in both sets, whereas rest parameters were measured only in the second set of experiments (starved for $26 \mathrm{~h}$ ).

Blood collection. For blood collection after starvation, mice were euthanized with $\mathrm{CO}_{2}$ as described above and the retro-orbital sinus was punctured with a non-heparinized glass capillary $(1.0 \mathrm{~mm}$ in diameter) to collect a blood sample. Blood samples were divided into two portions, both of which were collected in tubes with heparin. The major portion was centrifuged ( $1500 \mathrm{~g}, 15 \mathrm{~min}, 4^{\circ} \mathrm{C}$ ) to separate plasma and cells. The resulting blood plasma was used to run clinical biochemistry and kept on ice $\left(0-4{ }^{\circ} \mathrm{C}\right)$ prior for analysis. The smaller portion of the blood sample was used immediately for hematological analyses.

Determination of hematological parameters. Total hemoglobin $(\mathrm{Hb})$ concentration was determined in whole blood by the cyanmethaemoglobin spectrophotometric method with Drabkin's reagent using a commercial kit (Genesis Co, Ltd., Ukraine) according to the manufacturer's instructions. Drabkin's reagent induces hemolysis of erythrocytes and the released $\mathrm{Hb}$ reacts irreversibly with potassium cyanide and potassium ferricyanide with formation a stable pigment cyanmethaemoglobin with an absorbance peak at $540 \mathrm{~nm}$. Blood aliquots $(0.02 \mathrm{ml})$ were mixed with $5 \mathrm{ml}$ Drabkin's reagent. After 20 min of incubation at room temperature, the absorbance of cyanmethaemoglobin formed was measured at $540 \mathrm{~nm}$. Data are expressed as grams of $\mathrm{Hb}$ per liter of whole blood (g/l).

Other aliquots of $0.01 \mathrm{ml}$ of blood were diluted 1:400 in $4 \mathrm{ml}$ of $3 \% \mathrm{NaCl}$ and were used to determine erythrocyte counts. For determination of leucocyte counts, $0.02 \mathrm{ml}$ aliquots of blood were mixed with $0.4 \mathrm{ml}$ of $5 \% \mathrm{CH}_{3} \mathrm{COOH}$ solution tinted by methylene blue. Both erythrocyte and leucocyte counts were done manually using a Goryaev's chamber under a light microscope and were defined as $10^{3}$ cells per $\mathrm{mm}^{3}$ of blood, respectively [13].

The differential leucocyte count (leucocyte formula) was calculated by examining a stained peripheral blood smear. For that, small drops of whole blood were directly smeared on glass slides and air-dried. Smears were then fixed and stained with a Romanovsky stain (water solution of azureeosine) and then with eosin methylene by the MayGrunewald-Giemsa technique [13, 14]. Two hundred cells were then counted at $\times 1000$ magnification using a Leitz microscope (Leitz Wetzbar GmbH, Germa- ny) and classified according to [15]. The percentage of different types of leukocytes was then calculated.

Determination of biochemical indices. Biochemical analyses were performed with Spekol 211 (Carl Zeiss Jena, Jena, Germany) spectrophotometer or a Multiskan MCC/340 microplate reader (Labsystems, Helsinki, Finland). Concentrations of plasma glucose, triglycerides (TAG), and total cholesterol, as well as activities of alanine aminotransferase (ALT), aspartate aminotransferase (AST), and alkaline phosphatase (ALP) were measured by colorimetric methods using diagnostic kits from "Phyllis-Diagnosis" (Dnipro, Ukraine) following the manufacturer's instructions. Concentrations of glucose, TAG, and total cholesterol were expressed in millimoles per liter of blood plasma (mmol/l). Lactate dehydrogenase (LDH) activity was measured by monitoring NADH oxidation at $340 \mathrm{~nm}$ in a reaction mixture containing $50 \mathrm{mM}$ potassium phosphate buffer ( $\mathrm{pH}$ 7.5), $0.5 \mathrm{mM}$ EDTA, $0.2 \mathrm{mM}$ NADH, $1 \mathrm{mM}$ pyruvate, and 5-25 $\mu \mathrm{l}$ of blood plasma in a final volume of $1.0 \mathrm{ml}$ [16]. The extinction coefficient for NADH of $6.22 \mathrm{mM}^{-1} \cdot \mathrm{cm}^{-1}$ was used for calculations. One unit of ALT, AST, ALP, or LDH activity was defined as the amount of the enzyme consuming $1 \mu \mathrm{mol}$ of substrate or generating $1 \mu \mathrm{mol}$ of product per minute; activities were expressed as international units or milliunits per milligram of soluble protein (U/mg protein). Soluble protein concentration was determined using the Coomassie Brilliant blue G-250 method [17], with using bovine serum albumin as the standard.

To determine lactate levels, aliquots of blood plasma were mixed with $0.5 \mathrm{M} \mathrm{HClO}_{4}$ at a ratio 1:2.5 to precipitate protein and centrifuged (13 $000 \mathrm{~g}$, $15 \mathrm{~min}, 21^{\circ} \mathrm{C}$ ). The resulting supernatants were neutralized with $2 \mathrm{M} \mathrm{KOH}$. The concentration of lactate was determined by the Cuddihee and Fonda method [18], based on the oxidation of lactate to pyruvate by lactate dehydrogenase followed by $\mathrm{NAD}^{+}$reduction. The increase of absorbance of NADH at $340 \mathrm{~nm}$ was proportional to lactate concentrations. To avoid the reverse reaction (from pyruvate to lactate), hydrazine, which forms complex with pyruvate, was added. The reaction mixture contained $0.5 \mathrm{M}$ glycine-hydrazine buffer ( $\mathrm{pH}$ 9.0), $2 \mathrm{U} / \mathrm{ml} \mathrm{LDH}, 2 \mathrm{mM}$ $\mathrm{NAD}^{+}$and $50 \mu \mathrm{l}$ of neutralized supernatant in a final volume of $1 \mathrm{ml}$. Lactate solutions ranging from 10 to $160 \mathrm{mM}$ were used to create a calibration curve. Results are expressed as millimoles lactate per liter of blood plasma (mmol/l). 
Statistical analysis. All results are presented as mean \pm standard error of the mean (S.E.M) as assessed by Mynova software and using a two-tailed Student's $t$-test to compare respective values between control and EOD groups or between sexes. Differences with value of $P<0.05$ were considered to be statistically significant.

\section{Results and Discussion}

The experiments were carried out in two designs: in the first design experimental animals (i.e. receiving IF or EOD protocols) before sampling were starved for $2 \mathrm{~h}$ (IF2S group), whereas in the second design experimental animals were starved for $26 \mathrm{~h}$ (IF26S group) before sampling. In both experimental cases, control mice were fed ad libitum and starved for $2 \mathrm{~h}$ before sampling. Therefore, the first design (IF2S group) actually repeated the control in the time of animal starvation after a previous feeding day.

Mouse body mass and food consumed. In order to avoid an influence on animal mass from a previous fasting day, for evaluation of body mass, we present data from the IF2S group versus controls. As shown in Fig. 1, $A$, the body mass of animals in all four groups increased over time and control mice of both sexes were heavier than their IF counterparts. At the end of the time course, males in the control group were $17 \%$ heavier than IF males, whereas control females were $15 \%$ heavier than fasted ones (both differences were statistically significant with $P<0.05)$. Such body mass dynamics over the experimental period corresponds well to the mass of food consumed. During the experiment the cumulative amount of food consumed also increased, but not proportionally to body mass: initially it increased faster and near the end of the experimental month the increase was lower (Fig. 1, B). At the last feeding point (from $25^{\text {th }}$ to $31^{\text {th }}$ day) the data show that control male mice ate 1.46-fold more than experimental ones and females control 1.53-fold more than their experimental ones. This means that in our hands the mice that experienced intermittent fasting mice received about $30-35 \%$ less food that their ad libitum fed counterparts. In other words, generally IF the animals were restricted in the amount of food eaten by about one third over the one month experiment.

Levels of plasma glucose, lactate, TAG, and activities of ALT and AST. Levels of glucose, lactate and total cholesterol in plasma of control groups in both experiments (with IF2S or IF26S counterparts) were virtually the same (their numbers did not differ statistically). In EOD mice, which were starved before killing for $2 \mathrm{~h}$ (IF2S group), the plasma glucose level showed just a small tendency (not significant) to be lower than values in the control cohort (Fig. 2, A). However, when EOD animals were sampled after to $26 \mathrm{~h}$ total food deprivation (IF26S group) both
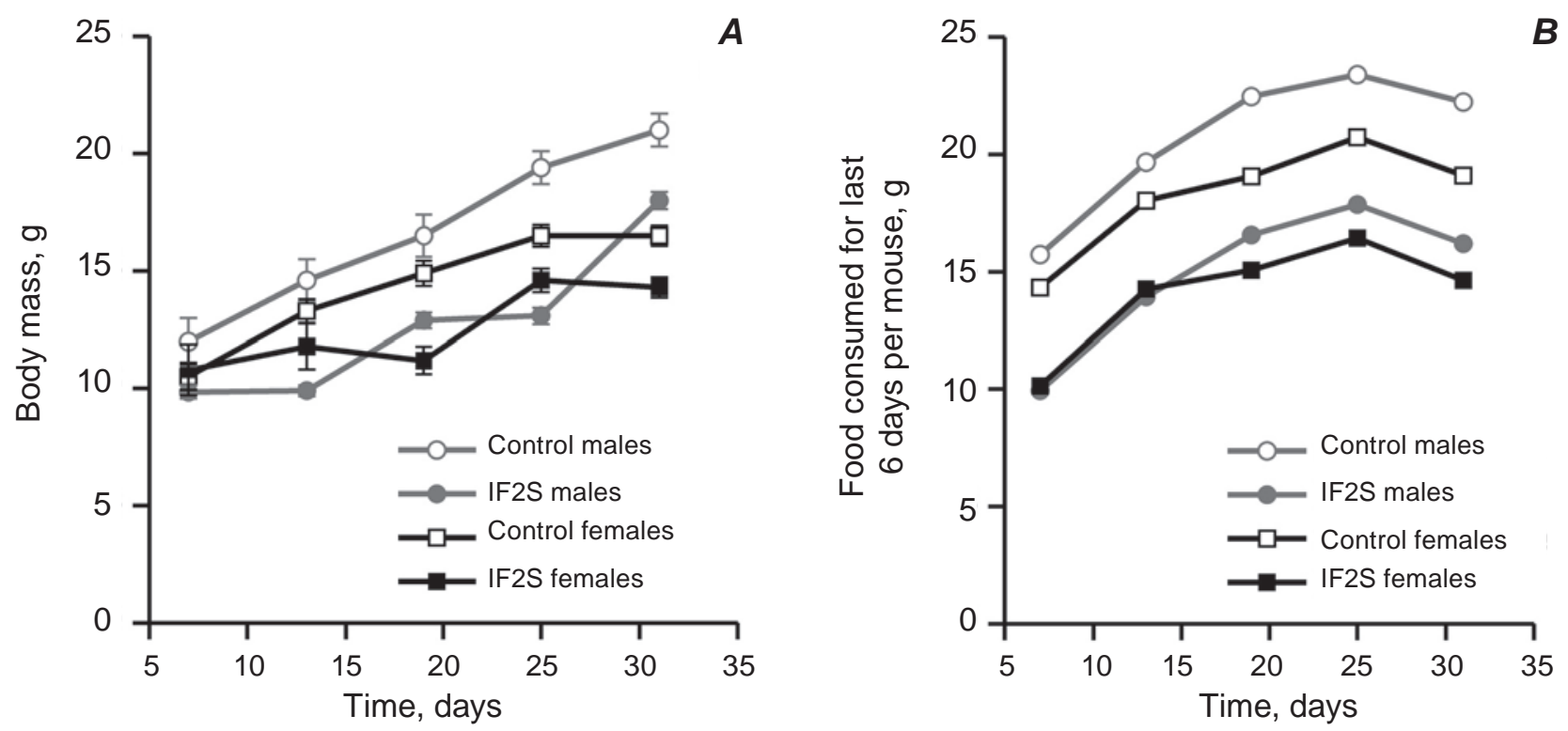

Fig. 1. Dynamics of body mass (A) and average cumulative food intake (B) in male and female mice fed ad libitum (control) or subjected to an intermittent fasting regime (IF) over one month (data gathered every six days starting from $7^{\text {th }}$ day). (A) Data are presented as means \pm SEM, $n=6-7$ 

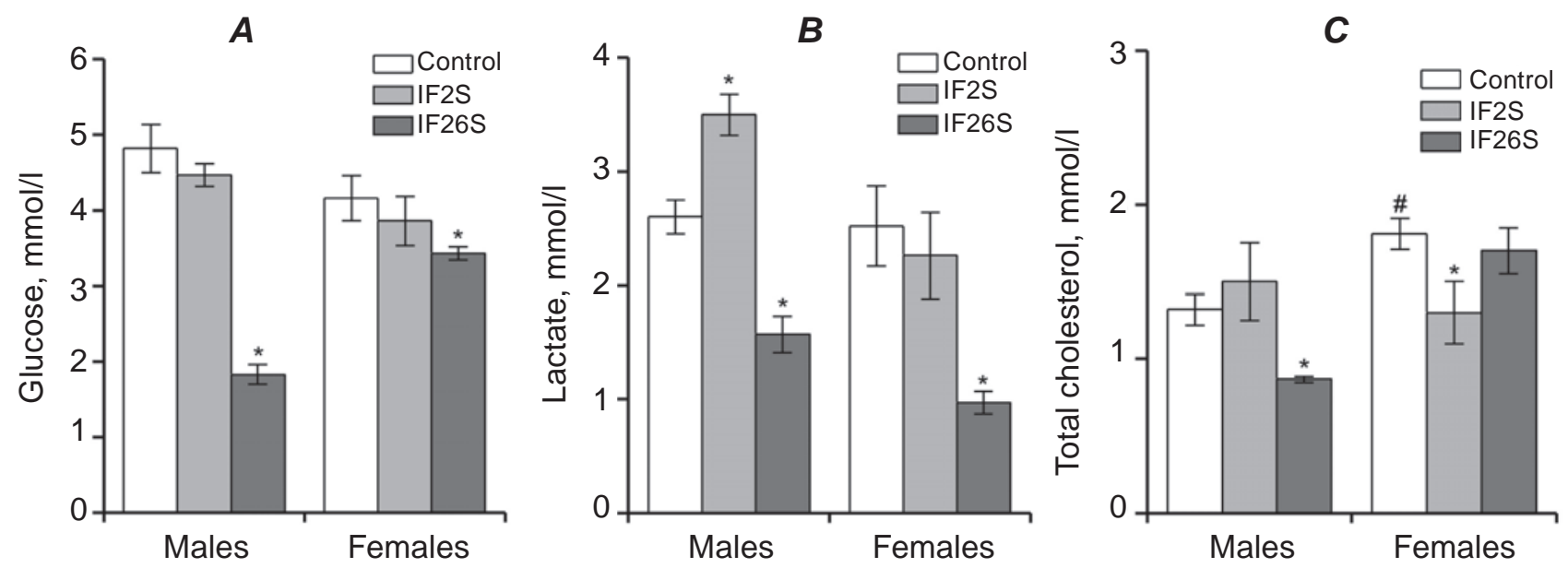

Fig. 2. Plasma glucose (A), lactate (B), and cholesterol (C) concentrations in two-month-old mice fed ad libitum (control) or subjected to an intermittent fasting regime (IF) over one month. Before blood sampling, mice were starved for $2 \mathrm{~h}$ in control groups and 2 h (IF2S) or 26 h (IF26S) in IF groups. Data are presented as means $\pm S E M, n=5-15$. *Significantly different from the control group $(P<0.05)$

sexes showed plasma glucose levels that were significantly lower than those in the ad libitum fed mice. In males glucose concentration had fallen to just $38 \%$ of the AL value whereas in females the value was $82 \%$ of the control group (Fig. 2, A). No sex difference between plasma glucose levels in control groups was found.

Plasma lactate concentrations behaved similarly to glucose ones except for the group of IF2S males where lactate was significantly higher than the AL group (by 34\%) (Fig. 2, B). However, plasma lactate levels in $26 \mathrm{~h}$ starved mice were only $60 \%$ in males and $38 \%$ in females, relative to their control groups. Lactate concentrations in control males and females were virtually the same.

Levels of plasma triacylglycerides (TAG) were $1.35 \pm 0.10$ and $1.30 \pm 0.20 \mu \mathrm{mol} / \mathrm{l}$ in control males and females, respectively (not shown). In the IF26S male group TAG concentration had fallen to 59\% of the control cohort parameter, whereas in females there was no difference in this parameter between experimental and control groups.

The concentrations of total cholesterol in plasma of IF2S group females were $72 \%$ of those in ad libitum fed mice, whereas in IF26S males they were $66 \%$ of the value in the corresponding control group (Fig. 2, C). Total plasma cholesterol in control females exceeded that in males by $37 \%$.

Next we evaluated the activities of alanine aminotransferase (ALT) and aspartate aminotransferase (AST) in plasma of control and IF groups (Table 1). Unexpectedly, the activities of ALT and AST in plasma of control mice in the two independent experiments, namely IF2S and IF26S, differed in all cases excepting ALT controls for females (Table 1). The activities of the two aminotransferases were not affected by fasting in either sex of the IF2S groups. But in the IF26S groups, in male plasma the AST activity was 1.80 -fold higher than its control and in female plasma the ALT activity was 2.44-fold higher than that in the control. Finally, the activities of both aminotransferases were higher in females than those in the corresponding males except for ALT activity in the control groups and AST activity in IF2S groups (Table 1).

The activity of lactate dehydrogenase (LDH) in mouse blood plasma was $36 \%$ higher in the experimental male group (IF26S) than that in male controls, but in females LDH was $12 \%$ lower in the experimental group. Furthermore, LDH activity in female controls was 38\% higher than the activity in control males (Table 1). The activity of alkaline phosphatase (ALP) was virtually the same in experimental and control groups as well as between the two sexes (Table 1).

Whole blood parameters. All parameters in the blood were evaluated only in control and IF26S experimental groups. The concentration of hemoglobin was virtually the same in both experimental and control groups, and no sex difference was seen (Fig. 3, A). In males, the number of erythrocytes was $36 \%$ higher in the experimental group than that in the controls, whereas no difference between these groups was found in females. Erythrocyte counts 
Ta b le 1. The activities of alanine aminotransferase (ALT), aspartate aminotransferase (AST), lactate dehydrogenase (LDH) and alkaline phosphatase (ALP) in blood plasma of mice starved for 2 or $26 \mathrm{~h}$

\begin{tabular}{l|c|c|c|c|c|c}
\hline \multirow{2}{*}{ Parameters } & \multicolumn{3}{|c|}{ Males } & \multicolumn{3}{c}{ Females } \\
\cline { 2 - 7 } & Control & IF2S & IF26S & Control & IF2S & IF26S \\
\hline $\begin{array}{l}\text { ALT activity, } \\
\text { mU/mg protein }\end{array}$ & $256 \pm 39$ & $171 \pm 23^{*}$ & $298 \pm 39$ & $279 \pm 23$ & $316 \pm 16^{\#}$ & $664 \pm 44^{*, \#}$ \\
$\begin{array}{l}\text { AST activity, } \\
\text { mU/mg protein }\end{array}$ & $415 \pm 63$ & $333 \pm 65$ & $827 \pm 154^{*}$ & $845 \pm 168^{\#}$ & $344 \pm 86^{*}$ & $1373 \pm 139^{*, \#}$ \\
$\begin{array}{l}\text { LDH activity, } \\
\text { mU/mg protein }\end{array}$ & $11.3 \pm 0.1$ & ND & $15.4 \pm 0.1^{*}$ & $15.5 \pm 0.2^{\#}$ & ND & $13.7 \pm 0.1^{*}$ \\
$\begin{array}{l}\text { ALP activity, } \\
\text { U/mg protein }\end{array}$ & $3.01 \pm 0.06$ & ND & $2.98 \pm 0.13$ & $3.26 \pm 0.05$ & ND & $3.12 \pm 0.03$ \\
\hline
\end{tabular}

Data are presented as means \pm SEM, $n=5$-10. *Significantly different from the corresponding control group $(P<0.05)$, ${ }^{\#}$ from the corresponding group of males $(P<0.05)$. ND - parameter was not determined
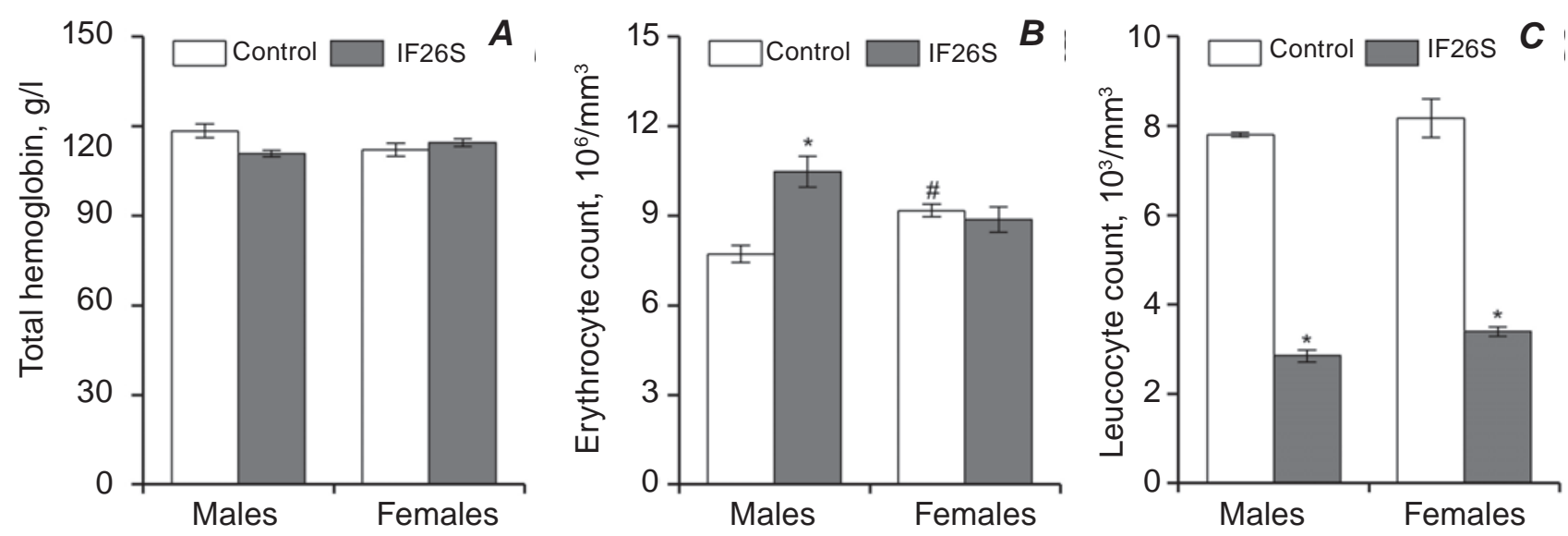

Fig. 3. Hematological parameters in mice starved for 26 hours (IF26S): total hemoglobin concentration (A), erythrocyte count (B), and leucocyte count (C). Data are presented as means $\pm S E M, n=6-8$. *Significantly different from the corresponding control group $(P<0.05)$, "from control males $(P<0.05)$

were $19 \%$ higher in female controls than in males (Fig. 3, B). Surprisingly, in both sexes, intermittent fasting lowered the amount of leucocytes by $63 \%$ in males and $58 \%$ in females, but with no differences between control males and females (Fig. 3, C). This clearly showed development of leucopenia in IF animals.

Since we found large differences in leucocyte counts (Fig. 3, C) between control and experimental groups, we next evaluated the relative amounts of different leucocyte forms (Table 2). No difference between control and IF groups was found for juvenile leucocyte forms as well as no statistically significant sex difference between the control groups. The count of band neutrophils did not differ between control and experimental groups, but in con- trol males showed an overall $41 \%$ higher number of these cells than female controls. The percentage of segmented neutrophils was $44 \%$ higher in the female IF26S group than in controls, but no significant difference was found between control groups of the two sexes. Basophile granulocytes were not found in any group. No statistically significant difference between experimental and control groups of eosinophil percentage was noticed. In males, the number of lymphocytes was not affected by IF, whereas in females IF26S animals possessed $11 \%$ fewer lymphocytes than controls. Between control groups lymphocyte numbers were $16 \%$ higher in females than in males. The monocyte percentage was not significantly different between any of the groups investigated. 
Ta ble 2. Leucocyte formula of peripheral blood of mice subjected to $26 \mathrm{~h}$ starvation

\begin{tabular}{l|c|c|c|c}
\hline \multirow{2}{*}{\multicolumn{1}{c}{ Cell type, \% }} & \multicolumn{2}{|c|}{ Males } & \multicolumn{2}{c}{ Females } \\
\cline { 2 - 5 } & Control & IF26S & Control & IF26S \\
\hline Juvenile forms & $4.20 \pm 0.80$ & $4.2 \pm 1.2$ & $3.5 \pm 1.0$ & $3.0 \pm 0.6$ \\
Band neutrophils & $10.9 \pm 1.8$ & $11.2 \pm 1.7$ & $4.5 \pm 0.7^{\#}$ & $4.7 \pm 0.8$ \\
Segmented neutrophils & $12.4 \pm 3.5$ & $14.9 \pm 3.4$ & $7.0 \pm 0.9$ & $15.8 \pm 1.8^{*}$ \\
Basophile granulocytes & $\mathrm{NF}$ & $\mathrm{NF}$ & $\mathrm{NF}$ & $\mathrm{NF}$ \\
Eosinophils & $0.8 \pm 0.4$ & $0.2 \pm 0.1$ & $1.1 \pm 0.5$ & $1.1 \pm 0.5$ \\
Lymphocytes & $69.3 \pm 3.4$ & $66.6 \pm 4.9$ & $80.5 \pm 2.7^{\#}$ & $72.4 \pm 3.3^{*}$ \\
Monocytes & $2.5 \pm 0.7$ & $3.1 \pm 1.0$ & $3.6 \pm 0.8$ & $3.0 \pm 0.7$ \\
\hline
\end{tabular}

Data are presented as means \pm SEM, $n=6$. *Significantly different from the corresponding control group $(P<0.05)$, \#from control males $(P<0.05)$. NF - not found

Like many humans, when a sufficient amount of food is available, laboratory mice will not only eat enough food but will often eat more than enough and become overweight or even obese. This can affect both life and health spans of both lab animals and humans, shortening these parameters relative to normally eating counterparts. Such overeating seems to result from comfort conditions when access to food is unlimited. The treatment of resulting obesity often involves the opposite strategy, i.e. limited access to food. Multiple studies, including some clinical ones, have used intermittent fasting as a weight loss treatment for obese and overweight adults [19-21]. Most such studies were carried out with adult populations. However, in some cases, young people and animals may undergo intermittent fasting, so it is important to know how young animals respond to fasting challenges. Therefore, the present work was designed to take relatively young mice and subject them to IF. The EOD regimen, also called alternate day fasting that we used, consisted of alternating 24-hour intervals of food deprivation followed by 24-hour ad libitum food access. Our study sought to record metabolic consequences of an intermittent fasting protocol in young mice by assessing both body weight changes and a variety of blood parameters. In particular, this approach allowed evaluation of a variety of vital techniques that could be used as markers to evaluate the physiological state of animals under IF, both in the present and future studies. An IF approach to food restriction also is preferable over a continuous food restriction regimen because in the latter case animals have to be held individually in a cage in order to ensure that each animal receives an exact food allotment. Since mice are social animals, individual housing may cause additional stress and, hence, holding animals in a group situation is more natural and acceptable. In addition, the EOD design, like other similar IF regimens, prevents competition between animals for food because they are provided with ad libitum food permanently during a feeding day and do not need to fight for forage.

In order to discover the responses of the blood system to IF in young mice, four-week old C57BL $\times$ sv129 mice were placed on an intermittent fasting regimen for four weeks. At the end of the fourth week, the IF mice of both sexes had body masses that were statistically lower than those of the control ones (Fig. 1). This seemed to be a minimal period of time needed to develop significant differences between ad libitum fed mice (control) and EOD ones. Several works on effects of IF on mouse weight were carried out with strain C57BL/6J (one of two maternal mouse strains, used in this work) and gave contradictory results [2, 12, 22-25]. In one of them, IF applied as EOD resulted in no differences in body mass between control and experimental groups for more than one month, whereas during the $7^{\text {th }}$ week mass started to differentiate and in the $20^{\text {th }}$ week a significant body mass difference was found [22]. Interestingly, in the same study food intake between control and experimental groups did not differ over the first weeks of the experiment, but from the $5^{\text {th }}$ week to the $13^{\text {th }}$ week IF mice consumed less food than their ad libitum fed counterparts did. Obese mice when placed on an IF diet started weigh less than ad libitum fed animals at about the $5^{\text {th }}$ week of the challenge [24]. The lower body mass of IF mice, compared with controls, found in the present study after 30 days of fasting corresponds to literature data where such differences ranged from 5 to $21 \%[12,23]$. Values similar to our data were also 
reported in other studies $[2,25]$. We also summarized the data on food consumption by control and IF mice over the experimental period and plotted the body mass as a function of the cumulative food eaten for both male and female mice (Fig. 4). In all cases, good linear relationships were seen with $\mathrm{R}^{2}$ values ranging from 0.77 to 0.99 indicating strong relationships between these two parameters. Fig. 4 also suggests that to achieve the same body mass IF animals needed both more time and more food than controls. Perhaps IF mice must direct some of their food/energy resources not only to growth, but also to deal with stress induced by the periodic changes in food supply. This hypothesis is supported by the higher oxygen consumption and carbon dioxide and heat production by IF mice as compared with ad libitum fed animals [2]. In addition, the mean respiratory exchange ratios (RER) in EOD mice showed high values during the feeding day and low RER values during the starvation day. This indicates that on feeding days the animals have a more active aerobic metabolism which may be accompanied by the development of oxidative stress, whereas recorded perturbations on fasting day may be interpreted as metabolic stress and can be associated with hunger. Interestingly, earlier we found that DR induced oxidative stress in fruit fly Drosphila melanogaster, whereas overeating induced obesity [26]. Generally, metabolic profiling experiments [2] indicated that positive effects of EOD in mice could be associated

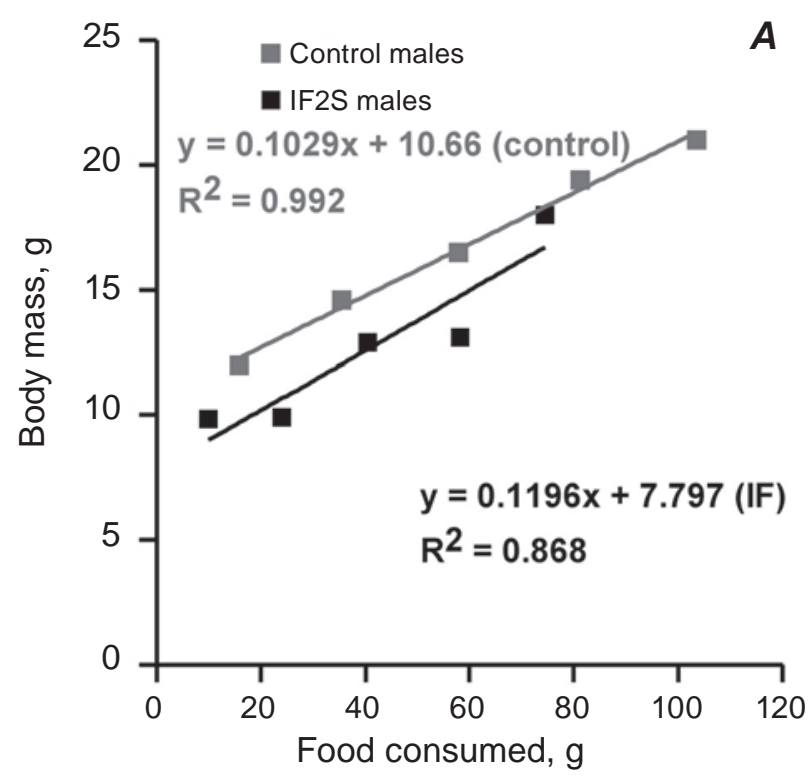

not with reduced, but rather with slightly increased rates of energy expenditure, that was as evidenced by body mass-adjusted oxygen consumption, carbon dioxide emission, heat production, and enhanced locomotor activity.

In most IF experiments reported in the literature, data were collected in the morning after a feeding day to avoid effects driven by hunger (see, for example, [2]). We also started with this design, but after measuring several parameters in plasma and understanding that most parameters followed patterns described in the literature for one or more mouse strains, we also developed a second protocol. In this protocol we began to collect data in the morning after a full fasting day in order to be able to determine if hunger after the $24 \mathrm{~h}$ fast may cause additional effects on blood parameters. In order to match IF groups with controls, this group was also subjected to two more hours of fasting in order that all animals would be sampled beginning at 11 a.m. Due to these designs we had two experimental groups: mice that were fasted for $2 \mathrm{~h}$ (IF2S) before sampling and mice that were fasted for $26 \mathrm{~h}$ (IF26S) before sampling. Because we wanted to measure parameters from fasted animals, the ad libitum fed group was subjected to fasting for $2 \mathrm{~h}$ before euthanizing, i.e. the food was taken from them at 9 a.m. on the sampling day.

Measurements of plasma glucose levels showed only a tendency to decrease in the IF2S group,

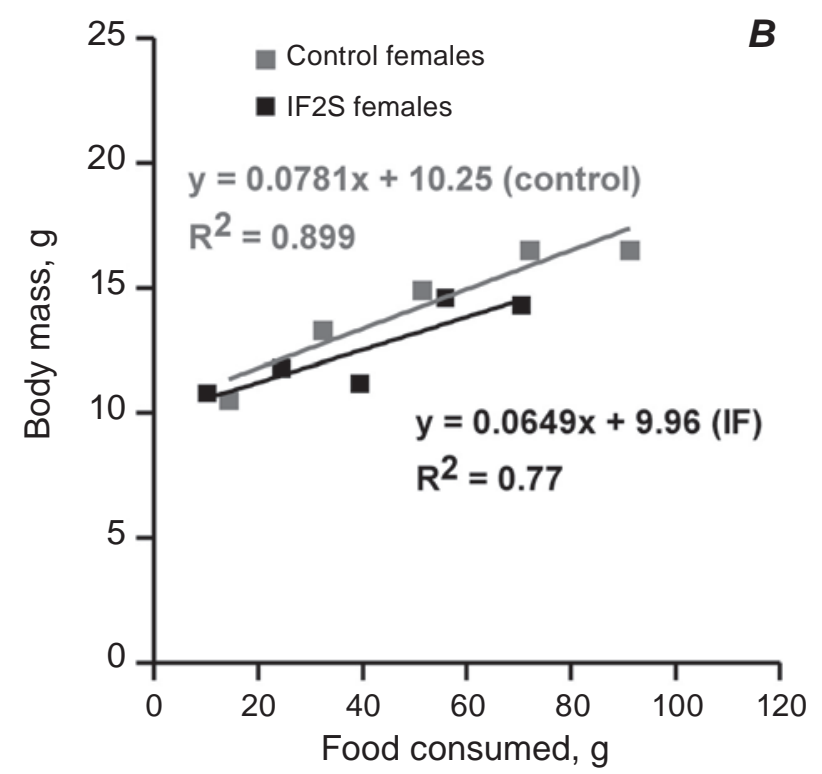

Fig. 4. Relationship between cumulative amounts of food consumed and body mass over time in males (A) and females $(\boldsymbol{B})$ 
whereas in the IF26S group both sexes demonstrated statistically lower glucose levels consistent with a day-long fast (Fig. 2, A). The data fit well with many studies in the literature [27-29] including those with IF animals $[2,22]$. The lactate data also complemented the glucose data and fit well with values reported in the literature [30]. Again, in the IF2S group a minor difference from controls was seen and males showed a slightly higher lactate level than control mice (Fig. 2, B). Again, however, the extension of the fasting period to $26 \mathrm{~h}$ in IF resulted in a significant reduction in blood lactate as compared to control groups. Probably such pattern reflects development of late stress situation resulting in exhausting easy available carbohydrate resources such as glucose or glycogen. Levels of TAG in our experiments also well corresponded to literature [31], but no difference on TAG level was found in the fasted group relatively to controls. A decrease in cholesterol levels (Fig. 2, C) such as seen in our study was also found by Xie and colleagues [2]. Alternatively, the data received can be explained that IF26S animals are relying more on lipid oxidation than are controls, or that controls are more active running around than fasting animals which could account for lower lactate in the IF group. Collectively, the data provided here indicate that mice are well adapted to IF and probably do not need to redistribute TAGs among different parts of mouse body. But enhanced plasma activities of ALT and AST (Table 1) in some cases along with increased LDH activity clearly show that EOD might provoke some damage to liver and heart with the resulting release of enzymes into the blood.

Whole blood parameters were evaluated only in the IF26S group because during the course of our experiments a paper with a very similar design to our IF2S condition was published by Xie and colleagues [2]. In our study, values for hemoglobin concentration and erythrocyte count in mouse blood corresponded well with to literature data [27, 29] and were not affected by IF except for the erythrocyte count in males that increased significantly under IF treatment (Fig. 3). Stress and emotional instability are important physiological factors that can cause a temporary increase in the number of erythrocytes, arising from their release by the spleen. In addition, we showed a higher erythrocyte count in blood of females, compared with males, as it was reported by other authors [32]. In control groups of both sexes, leucocyte counts were slightly higher than those reported in the literature [29] and intermittent fasting decreased strongly the leucocyte count in both males and females (Fig. 3, C). Similar results reporting reduced leucocyte counts under EOD were recently published [2] and confirm our findings of very substantial suppression of leucocyte levels during IF. Such decrease in leucocyte count at prolonged starvation was explained by as long periods of not eating lowers white blood cell counts flipping a regenerative switch to kill older and damaged immune cells and generate new ones [33, 34]. However, in this work we dealt with young mice due to which such explanation would need further clarification.

In our experiments, leucopenia in mice could cause an imbalance between leucocyte production in hematopoietic organs and destruction of mature leucocytes in the blood stream. The integral hematological indices based on determination of the ratio between different types of leucocytes (leucocyte formula) allowed us to evaluate the activity dynamics of nonspecific and specific animal immunity. In the present study, differential leucocyte counts showed an increase in the number of segmented neutrophils and a decrease in the number of lymphocytes in peripheral blood of the IF26S fasted group of females, but this did not occur in males. A modest increase in the number of neutrophils can occur under strong psycho-emotional stresses, as well as after intensified physical activity [35]. The percentage of band neutrophils was higher in males from both control and IF groups, compared to the corresponding values in females but control males had a lower percentage of lymphocytes in their blood than control females. The decrease in lymphocyte number in females might result from the migration of these cells from the blood vessels to the tissues. Quantitative and qualitative assessment of changes in leucocyte amounts and formula in peripheral blood provide a general understanding of the adaptive immune responses of an organism. Thus, the changes in total and differential leucocyte counts in IF mice could result from response of the mouse immune system to stress caused by the EOD regime.

Studies carried out to date on IF effects on mice have been mainly done on perhaps the most widely used highly homozygous laboratory strain C57BL/6J (see, for example, [2, 22]). Moreover, in the above cited papers only males were used. In addition, these studies mostly used only adult animals starting from two months and older. In order to extend our understanding of age-related IF effects the present study analyzed a rarely used heterozy- 
gote mixed C57BL $\times$ sv129 mice strain and analyzed young animals of both sexes (four weeks old when the study began followed by four weeks under IF) that were age-matched with controls. We applied an IF design similar to the commonly used every-otherday feeding (EOD) with sampling of experimental animals the next day after feeding to adjust to ad libitum fed ones (we called them IF2S and IF26S). One might expect that in young animals IF-induced stress could be greater than that on older ones due to extensive growth of one month old mice. The found IF-promoted changes show that experimental animals could suffer certain energy limitations. Decreased leucocyte count can be interpreted from one hand as negative because of possible weakening of immune system, or, on the other hand, as positive because indicates that inflammatory process in EOD mice were less intensive. Minor difference in leucocyte formula of peripheral blood of EOD mice well backs potential positive effects of fasting on operation of immune system.

Many studies, including this one, are designed to evaluate influence of relatively short term IF and include a rather limited number of parameters investigated. Due to this, long term effects along with broader amount of parameters of interest would have to be explored. This will help to uncover molecular mechanisms underlying IF effects partially recognized to date. Understanding of molecular mechanisms of beneficial influence of IF on organisms will open avenues to design interventions which will help improve health span. Therefore, the current study provides a foundation for the development of longterm studies with animals, which in future would be possible to transfer to humans. In conclusion, our data indicate that blood parameters can be efficiently used for vital monitoring of changes induced by intermittent fasting.

Acknowledgments. The work was partially supported by the grant \#90233 from Volkswagen Foundation (VolkswagenStiftung), Germany, and the grant from Ministry of Education and Science of Ukraine (\#0118U00347) to VIL and a discovery grant from the Natural Sciences and Engineering Research Council of Canada (\#6793) to KBS.

Conflict of interest. Authors have completed the Unified Conflicts of Interest form at http:// ukrbiochemjournal.org/wp-content/uploads/2018/12/ coi_disclosure.pdf and declare no conflict of interest.

\section{ПЕРІОДИЧНЕ ГОЛОДУВАННЯ СПРИЧИНЯЄ МЕТАБОЛІЧНИЙ СТРЕС І ЛЕЙКОПЕНІЮ В МОЛОДИХ МИШЕЙ}

\author{
О. М. Сорочинська 1 , М. М. Байляк 1 , \\ Ю. В. Василик', О. В. Кузняк ${ }^{1}$, \\ I. 3. Дрогомирецька ${ }^{1}$, А. Я. Клоновський \\ Дж. М. Сторі ${ }^{2}$, К. Б. Сторі ${ }^{2}$, В. І. Лущак $\kappa^{1 凶}$
}

\footnotetext{
${ }^{1}$ Прикарпатський національний університет імені Василя Стефаника, Івано-Франківськ, Україна; ${ }^{2}$ Інститут біохімії, Карлетонський університет, Оттава, Канада; 凶e-mail: lushchak@pu.if.ua
}

Надмірна вага і ожиріння стали епідемією світового масштабу, що є наслідком переїдання, особливо у разі дотримання так званої західної дієти, збагаченої на вуглеводи та жири. Відомо, що за таких умов обмеження споживання їжі та зміна її складу можуть бути дієвими для дорослих організмів. Водночас, інформація щодо дієвості обмеженого харчування для молодих особин суперечлива. Метою нашого дослідження було охарактеризувати вплив періодичного голодування 3 використанням протоколу голодування/годівлі через день на біохімічні та гематологічні показники в молодих мишей віком від одного до двох місяців. Показано, що миші, які періодично голодували, мали меншу вагу, нижчий вміст глюкози та лактату, нижчу загальну кількість лейкоцитів, а також вищу активність аланінамінотрансферази та аспартатамінотрансферази в крові, ніж контрольні особини відповідної вікової групи. Тварини, що голодували, були змушені спожити більше їжі, щоб досягти тієї ж маси тіла, що і в тварин, які мали необмежений доступ до їжі. Можливо, ці відмінності пояснюються необхідністю затратити певні ресурси для боротьби зі стресом, спричиненим періодичним голодуванням. Загалом, наші результати свідчать про те, що періодичне голодування в молодому віці може негативно вплинути на організм молодих ссавців.

Кл ю чов і с лов а: амінотрансферази, плазма крові, глюкоза, лейкоцитарна формула, періодичне голодування. 


\section{References}

1. Mattson MP, Longo VD, Harvie M. Impact of intermittent fasting on health and disease processes. Ageing Res Rev. 2017; 39: 46-58.

2. Xie K, Neff F, Markert A, Rozman J, Aguilar-Pimentel JA, Amarie OV, Becker L, Brommage R, Garrett L, Henzel KS, Hölter SM, Janik D, Lehmann I, Moreth K, Pearson BL, Racz I, Rathkolb B, Ryan DP, Schröder S, Treise I, Bekeredjian R, Busch DH, Graw J, Ehninger G, Klingenspor M, Klopstock T, Ollert M, Sandholzer M, Schmidt-Weber C, Weiergräber M, Wolf E, Wurst W, Zimmer A, Gailus-Durner V, Fuchs H, Hrabě de Angelis M, Ehninger D. Every-other-day feeding extends lifespan but fails to delay many symptoms of aging in mice. Nat Commun. 2017; 8(1): 155.

3. Ma L, Wang R, Dong W, Li Y, Xu B, Zhang J, Zhao Z. Long-term caloric restriction in mice may prevent age-related learning impairment via suppression of apoptosis. Behav Brain Res. 2016; 315: 45-50.

4. Ntsapi C, Loos B. Caloric restriction and the precision-control of autophagy: A strategy for delaying neurodegenerative disease progression. Exp Gerontol. 2016; 83: 97-111.

5. Parikh I, Guo J, Chuang KH, Zhong Y, Rempe RG, Hoffman JD, Armstrong R, Bauer B, Hartz AM, Lin AL. Caloric restriction preserves memory and reduces anxiety of aging mice with early enhancement of neurovascular functions. Aging (Albany NY). 2016; 8(11): 2814-2826.

6. Gratuze M, Julien J, Morin F, Marette A, Planel E. Differential effects of voluntary treadmill exercise and caloric restriction on tau pathogenesis in a mouse model of Alzheimer's disease-like tau pathology fed with Western diet. Prog Neuropsychopharmacol Biol Psychiatry. 2017; 79(Pt B): 452-461.

7. Salvatore MF, Terrebonne J, Cantu MA, McInnis TR, Venable K, Kelley P, Kasanga EA, Latimer B, Owens CL, Pruett BS, Yu Y, Luedtke R, Forster MJ, Sumien N, Ingram DK. Dissociation of striatal dopamine and tyrosine hydroxylase expression from aging-related motor decline: Evidence from Calorie Restriction Intervention. J Gerontol A Biol Sci Med Sci. 2017; 73(1): 11-20.

8. Wahl D, Cogger VC, Solon-Biet SM, Waern RV, Gokarn R, Pulpitel T, Cabo Rd, Mattson MP, Raubenheimer D, Simpson SJ, Le Couteur DG.
Nutritional strategies to optimise cognitive function in the aging brain. Ageing Res Rev. 2016; 31: 80-92.

9. Antoni R, Johnston KL, Collins AL, Robertson MD. Effects of intermittent fasting on glucose and lipid metabolism. Proc Nutr Soc. 2017; 76(3): 361-368.

10. Speakman JR, Mitchell SE. Caloric restriction. Mol Aspects Med. 2011; 32(3): 159-221.

11. Weindruch R, Walford RL. Dietary restriction in mice beginning at 1 year of age: effect on lifespan and spontaneous cancer incidence. Science. 1982; 215(4538): 1415-1418.

12 Jensen TL, Kiersgaard MK, Sørensen DB, Mikkelsen LF. Fasting of mice: a review. Lab Anim. 2013; 47(4): 225-240.

13. Rathkolb B, Fuchs H, Gailus-Durner V, Aigner B, Wolf E, Hrabě de Angelis M. Blood collection from mice and hematological analyses on mouse blood. Curr Protoc Mouse Biol. 2013; 3(2): 101-119.

14. Houwen B. Blood film preparation and staining procedures. Clin Lab Med. 2002; 22(1): 1-14.

15. Löffler H, Rastetter J, Haferlach T. Atlas of clinical hematology. 6th revised ed. Springer, 2005. $429 \mathrm{p}$.

16. Lushchak VI. Influence of polyethylene glycol on lactate dehydrogenase. Biochem Mol Biol Int. 1998; 44(2): 425-431.

17. Bradford MM. A rapid and sensitive method for the quantitation of microgram quantities of protein utilizing the principle of protein-dye binding. Anal Biochem. 1976; 72: 248-254.

18. Cuddihee RW, Fonda ML. Concentrations of lactate and pyruvate and temperature effects on lactate dehydrogenase activity in the tissues of the big brown bat (Eptesicus fuscus) during arousal from hibernation. Comp Biochem Physiol B. 1982; 73(4): 1001-1009.

19. Varady KA. Impact of intermittent fasting on glucose homeostasis. Curr Opin Clin Nutr Metab Care. 2016; 19(4): 300-302.

20. Hall KD, Chung ST. Low-carbohydrate diets for the treatment of obesity and type 2 diabetes. Curr Opin Clin Nutr Metab Care. 2018; 21(4): 308-312.

21. Harris L, Hamilton S, Azevedo LB, Olajide J, De Brún C, Waller G, Whittaker V, Sharp T, Lean M, Hankey C, Ells L. Intermittent fasting interventions for treatment of overweight and obesity in adults: a systematic review and meta- 
analysis. JBI Database System Rev Implement Rep. 2018; 16(2): 507-547.

22. Anson RM, Guo Z, de Cabo R, Iyun $\mathrm{T}$, Rios M, Hagepanos A, Ingram DK, Lane MA, Mattson MP. Intermittent fasting dissociates beneficial effects of dietary restriction on glucose metabolism and neuronal resistance to injury from calorie intake. Proc Natl Acad Sci USA. 2003; 100(10): 6216-6220.

23. Ayala JE, Bracy DP, McGuinness OP, Wasserman DH. Considerations in the design of hyperinsulinemic-euglycemic clamps in the conscious mouse. Diabetes. 2006; 55(2): 390397.

24. Joslin PMN, Bell RK, Swoap SJ. Obese mice on a high-fat alternate-day fasting regimen lose weight and improve glucose tolerance. J Anim Physiol Anim Nutr (Berl). 2017; 101(5): 10361045.

25. Li G, Xie C, Lu S, Nichols RG, Tian Y, Li L, Patel D, Ma Y, Brocker CN, Yan T, Krausz KW, Xiang R, Gavrilova O, Patterson AD, Gonzalez FJ. Intermittent fasting promotes white adipose browning and decreases obesity by shaping the gut microbiota. Cell Metab. 2017; 26(5): 801.

26. Rovenko BM, Kubrak OI, Gospodaryov DV, Perkhulyn NV, Yurkevych IS, Sanz A, Lushchak OV, Lushchak VI. High sucrose consumption promotes obesity whereas its low consumption induces oxidative stress in Drosophila melanogaster. J Insect Physiol. 2015; 79: 42-54.

27. Serfilippi LM, Pallman DR, Russell B. Serum clinical chemistry and hematology reference values in outbred stocks of albino mice from three commonly used vendors and two inbred strains of albino mice. Contemp Top Lab Anim Sci. 2003; 42(3): 46-52.

28. Fernández I, Peña A, Del Teso N, Pérez V, Rodríguez-Cuesta J. Clinical biochemistry parameters in $\mathrm{C} 57 \mathrm{BL} / 6 \mathrm{~J}$ mice after blood collection from the submandibular vein and retroorbital plexus. J Am Assoc Lab Anim Sci. 2010; 49(2): 202-206.

29. Santos EW, Oliveira de DC, Hastreiter A, de Silva GB, de Beltran JSO, Tsujita M, Crisma AR, Neves SMP, Fock RA, Borelli P. Hematological and biochemical reference values for C57BL/6, Swiss Webster and BALB/c mice. Braz J Vet Res Anim Sci. 2016; 53(2): 138.

30. Suhara T, Hishiki T, Kasahara M, Hayakawa N, Oyaizu T, Nakanishi T, Kubo A, Morisaki H, Kaelin WG Jr, Suematsu M, Minamishima YA. Inhibition of the oxygen sensor PHD2 in the liver improves survival in lactic acidosis by activating the Cori cycle. Proc Natl Acad Sci USA. 2015; 112(37): 11642-11647.

31. Tatulli G, Mitro N, Cannata SM, Audano M, Caruso D, D'Arcangelo G, Lettieri-Barbato D, Aquilano K. Intermittent fasting applied in combination with rotenone treatment exacerbates dopamine neurons degeneration in mice. Front Cell Neurosci. 2018; 12: 4.

32. Schnell MA, Hardy C, Hawley M, Propert KJ, Wilson JM. Effect of blood collection technique in mice on clinical pathology parameters. Hum Gene Ther. 2002; 13(1): 155-161.

33. Choi IY, Lee C, Longo VD. Nutrition and fasting mimicking diets in the prevention and treatment of autoimmune diseases and immunosenescence. Mol Cell Endocrinol. 2017; 455: 4-12.

34. Cheng CW, Adams GB, Perin L, Wei M, Zhou X, Lam BS, Da Sacco S, Mirisola M, Quinn DI, Dorff TB, Kopchick JJ, Longo VD. Prolonged fasting reduces IGF-1/PKA to promote hematopoietic-stem-cell-based regeneration and reverse immunosuppression. Cell Stem Cell. 2014; 14(6): 810-823.

35. Hickman DL. Evaluation of the neutrophil:lymphocyte ratio as an indicator of chronic distress in the laboratory mouse. Lab Anim (NY). 2017; 46(7): 303-307. 